\title{
Pollutant abatement of unhairing-liming workshop of a tannery unit by non-thermal gliding discharge in air
}

\author{
Abba Paltahe ${ }^{1,2}$, Samuel Laminsi ${ }^{1}$, Jean-Louis Brisset ${ }^{3}$ \\ ${ }^{1}$ Department of Inorganic Chemistry, Faculty of Science, University of Yaoundé I, P.O.BOX. 812 Yaoundé, Cameroon \\ ${ }^{2}$ Department of Chemistry, Higher Teachers' Training College, University of Maroua, P.O.BOX.55 Maroua, Cameroon \\ ${ }^{3}$ UFR Sciences, University of Rouen, 76821 Mont-Saint-Aignan, France
}

\section{Email address:}

abbapaltahe@yahoo.fr (A. Paltahe), s.laminsi@yahoo.fr (S. Laminsi), brissj1@club-internet.fr (Jean-Louis B.)

\section{To cite this article:}

Abba Paltahe, Samuel Laminsi, Jean-Louis Brisset. Pollutant Abatement of Unhairing-Liming Workshop of a Tannery Unit by Non-Thermal Gliding Discharge in Air. International Journal of Environmental Protection and Policy. Vol. 2, No. 6, 2014, pp. $200-204$.

doi: 10.11648/j.ijepp.20140206.11

\begin{abstract}
The effluents of an unhairing-liming workshop of a craft tannery in North Cameroon are exposed to a gliding arc discharge for various exposure times in a cold plasma reactor. The highly basic effluent is rich in concentrated organic wastes which are degraded by the oxidizing species formed in the discharge. Total Organic Carbon (TOC) and Biological Oxygen Demand $\left(\mathrm{BOD}_{5}\right)$ abatements by $95 \%$ and more than $90 \%$ respectively result from one hour treatment in batch conditions. Simultaneously $\mathrm{pH}$ trends to acid. Bacterial inactivation was also found successful for short exposures $\mathrm{t} *<10 \mathrm{~min}$. The feasibility of the plasma technique is then confirmed in case of actual effluents at the laboratory scale and may be developed in view of industrial applications by valuable improvements.
\end{abstract}

Keywords: Gliding Arc Discharge, Humid Air, Tannery Effluents, Wastewaters, Peroxynitrite

\section{Introduction}

Solving the acute pollution problems that affect our planet is one of the main tasks for the $\mathrm{XXI}^{\text {th }}$ Century, by developing green chemistry, modifying the usual processes (especially by deleting those requiring organic solvents) and developing techniques for pollutant abatement that could be used before green and sustainable chemistry took the place of conventional methods. There is a long remaining way to progress for numerous countries, especially the developing ones, where handicrafts remain largely developed. In numerous cases, the liquid effluents are thrown out in riots outside plant without any purification device. A large number of countries are directly concerned with serious public health problems in connection with pollution. They thus acutely interested in operating new efficient processes, to ensure an easy transition to a suitable sewer network with adapted purifying systems. They are thus concerned with Advanced Oxidation Processes (AOP) which are collectively characterized by involving ${ }^{\circ} \mathrm{OH}$ radicals as strong oxidizer are famed for being easy to operate, efficient and occasionally cheap and over all robust techniques. A newly developed AOP involves electrical discharges at atmospheric pressure, and among them, the gliding arc device seems to be among the most efficient. The gliding discharge (or "glidarc") was found successful in pollutant abatement of domestic and industrial wastewaters [1-3] as well as for degrading industrial waste solvents [4] and even recalcitrant molecules [5]. The process is also highly effective for bacterial inactivation [6]. The objective of this study is to reduce the pollution load of the effluents of an unhairing-liming workshop.

\subsection{The Gliding Discharge and its Relevant Chemistry}

The gliding discharge [7] proposed by Czernichowski for the treatment of gases, is originally an arc, i.e., thermal plasma burning at atmospheric pressure between two diverging electrodes. The arc forms at the narrowest electrode gap and moves to the electrode tips by a gas flow (usually humid air in our case) disposed along the reactor axis. The arc length increases, its temperature falls until it is short-circuited by a new arc. Then it bursts in a plasma cloud at atmospheric pressure and close to ambient temperature. An aqueous solution is exposed to the quenched plasma plume.

Energy brought by the arc channel is dissipated in the surrounding gas, i.e., humid air in the present case, breaks 
water molecules, forms nitric oxide according to the Birkland process and thus generates Reactive Oxygen Species (ROS) and Reactive Nitrogen Species (RNS). The occurrence of ${ }^{\circ} \mathrm{OH}$ and ${ }^{\circ} \mathrm{NO}$ was evidenced by emission spectroscopy and the relevant population estimated [8]. These species react together and with the ambient gas and yield various species, the most active ones are the dimer $\mathrm{H}_{2} \mathrm{O}_{2}$ and peroxynitrite $\mathrm{ONOO}^{-}$(and the matching acid) [9]. $\mathrm{ONOOH}$ is granted with marked nitrating/nitrosing properties which are determining in the degradation process of bacterial cells $[9,10]$; additionally both hydrogen peroxide and peroxynitrite are strong oxidizers [9]: $\mathrm{E}^{\circ}\left(\mathrm{H}_{2} \mathrm{O}_{2} / \mathrm{H}_{2} \mathrm{O}\right)=1.76 \mathrm{~V} / \mathrm{SHE}$; $\mathrm{E}^{\circ}\left(\mathrm{ONOOH} / \mathrm{NO}_{2}\right)=2.05 \mathrm{~V} / \mathrm{SHE} ; \mathrm{E}^{\circ}\left(\mathrm{ONOO}^{-} / \mathrm{NO}_{2}\right)=2.44$ $\mathrm{V} / \mathrm{SHE}$

Other compounds are of more limited importance, e.g., $\mathrm{O}_{3}$ and $\mathrm{HO}_{2}{ }^{\circ}$, because these oxidizers are present only in small quantities $[9,10]$. For comparison purpose, the standard oxidation potentials of the concerned oxidizers are as follows $\mathrm{E}^{\circ}\left({ }^{\circ} \mathrm{OH} / \mathrm{H}_{2} \mathrm{O}\right)=2.85 \mathrm{~V} / \mathrm{SHE} ; \mathrm{E}^{\circ}\left(\mathrm{O}_{3} / \mathrm{H}_{2} \mathrm{O}\right)=1.51 \mathrm{~V} / \mathrm{SHE} ;$ $\mathrm{E}^{\circ}\left({ }^{\circ} \mathrm{HO}_{2} / \mathrm{H}_{2} \mathrm{O}\right)=1.63 \mathrm{~V} / \mathrm{SHE} ; \mathrm{E}^{\circ}\left(\mathrm{NO}_{2} / \mathrm{NO}\right)=1.05 \mathrm{~V} / \mathrm{SHE}$.

\subsection{A Case Study: A Glimpse over the Craft Industry of Tanning Operations}

A tanning craft industry is located close to Maroua (North Cameroon). This group of workshops gathers most activities of the tanning industry of the area, from collecting skins, washing, peeling or unhairing up to tanning, so that processed skins are later sent to other workshops for finishing and preparing leather goods.

The first step is devoted to unhairing the collected skins. The operation consists in steeping the untreated skins in an alkaline solution to weaken hair roots, and makes easier the removing of hair with a special knife. New processes have better using $\mathrm{NaOH}$ instead of $\mathrm{Ca}(\mathrm{OH})_{2}$ to get more supple leather. The basic solution also dissolves organic wastes stuck on hair. The skins are then dipped into a liming bath composed of alkaline sulphide which improves hair removing and modifies the skin proteins. The collagen swells and the skin pores open so that the further fixation of tanning agents is facilitated. The process then involves the deliming and pickling steps before the tanning operation itself.

The aqueous effluents released by all the workshops are gathered in a brook that passes through a nearby village, so that it is used as a source of drinking and washing water for people. The stream waters are also used for watering fields where food-producing crops are grown. This situation thus presents an important risk for public health and justifies that efficient improving solutions are taken. Several techniques were already proposed [11-13] and in particular ozonation ; this study is centered on the effluents of unhairing-liming steps and thus completes a specific work devoted to the glidarc treatment of the effluents of the tanning workshop [12].

\subsection{Main Characteristics of the Unhairing-Liming Workshop}

The unhairing-liming operations are usually performed in basic media (calcium hydroxide, sodium sulfite) to remove hair (keratine) and fats from the salted skins. The wastewaters effluents are therefore rich in $\mathrm{NaCl}$ and remaining hair because a complete hair removal and an alteration of the skin protein (collagen) are performed at this stage. Wastewaters from the unhairing-liming workshop are alkaline and also rich in sulfates, chlorides, nitrates and nitrites which agree with the high conductance values and the high concentration in Total Dissolved Solids (TDS). They also have high Total Organic Carbon (TOC) values. The concentration in hexavalent chromium is higher than that imposed by the standards in Cameroon, fixed to $0,1 \mathrm{mgL}^{-}$

1 .Thus, the liming produces highly toxic waste water containing large quantities of alkaline proteins and salts. High alkalinity is aimed to favour the hydrolysis reaction of keratin, i.e., the protein which is the major constituent of epidermis and hair. Table 1 gathers analytical data relevant to liming workshop effluents and Cameroon standards, which clearly shows that a suitable treatment of the effluents is necessary. Table 1 also shows the presence of fecal coliform bacteria. Such contamination may be due to fecal matter that has escaped previous washing steps. In any case, these occurring bacteria are a sign of actual epidemiological risk.

Table 1. Physicochemical properties and ion concentration of liming-unhairing workshop effluents.

\begin{tabular}{|c|c|c|c|c|}
\hline Parameter & Pollutant & Liming workshop effluents & Cameroon Standards & European Standards \\
\hline $\mathrm{pH}$ & & 13.2 & $6-9$ & \\
\hline Conductivity $\left(\mu \mathrm{Scm}^{-1}\right)$ & & 19800 & 1500 & \\
\hline $\operatorname{TDS}\left(\mathrm{mgL}^{-1}\right)$ & & 9950 & 1000 & \\
\hline $\mathrm{TOC}\left(\mathrm{mgL}^{-1}\right)$ & & 21450 & 50 & \\
\hline COD & & 9625 & 250 & \\
\hline BOD5 & & 17360 & 30 & \\
\hline \multirow{3}{*}{ Heavy metals } & Fecal Streptococci (CFU/100mL) & 0 & 0 & 0 \\
\hline & $\mathrm{Cr}(\mathrm{VI})\left(\mathrm{mgL}^{-1}\right)$ & 0.65 & 0.1 & 0.05 \\
\hline & $\mathrm{Cr}(\mathrm{III})\left(\mathrm{mgL}^{-1}\right)$ & n.d. & 2 & \\
\hline \multirow[t]{4}{*}{ Anions } & $\mathrm{Cl}^{-}\left(\mathrm{mgL}^{-1}\right)$ & 1290 & 250 & 200 \\
\hline & $\mathrm{NO}_{2}^{-}\left(\mathrm{mgL}^{-1}\right)$ & 435 & 30 & 0.1 \\
\hline & $\mathrm{NO}_{3}^{-}\left(\mathrm{mgL}^{-1}\right)$ & 702 & 50 & 50 \\
\hline & $\mathrm{SO}_{4}^{2-}\left(\mathrm{mgL}^{-1}\right)$ & 200 & 200 & 250 \\
\hline
\end{tabular}




\section{Materials and Methods}

Samples of waste solutions were obtained from the limingunhairing workshop and placed in a cylinder shaped $500 \mathrm{~mL}$ glass reactor fitted with a water cooling jacket and a magnetic stirrer (Fig.1).The plasma reactor was already described [1-3] and derives from Czernichowski device [7] : it consists in a couple of diverging electrodes connected with an energy source (i.e., a High Voltage transformer Aupem 9100 delivering $100 \mathrm{~mA} / 9 \mathrm{kV}$ in open and 160mA/600 V in working conditions) and disposed symmetrically around a wet air blowing nozzle. Wet air is obtained by bu bbling the air flow provided by a compressor through a Duran flask filled with distilled water. The air flow is monitored with a rotameter.

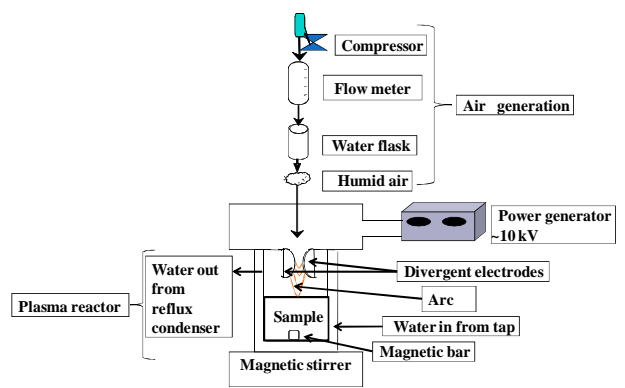

Fig. 1. Scheme of the laboratory scale batch plasma reactor
The reactor is operated in batch conditions for a better understanding of the degradation phenomena of organic wastes.

By switching on the electric circuit, an arc forms between the electrodes at the minimum gap (around $3 \mathrm{~mm}$ ) and is blown to the electrode tips by the axial gas flow. The arc then busts into a plasma cloud in contact with the liquid target when short-circuited by a new arc.

The sample solutions were exposed to the discharge for known times $t^{*}$ before being analyzed.

The analytical techniques of plasma treated solutions involve $\mathrm{pH}$-metry, conductimetry $\left(\mu \mathrm{S} \mathrm{cm}^{-1}\right)$ and the determination of totally dissolved solids TDS $\left(\mathrm{mg} \mathrm{L}^{-1}\right)$ : all these operations were performed by means of a portable Hanna multimeter. Total Organic Carbon (TOC, $\mathrm{mgL}^{-1}$ ) is measured by means of a TOC-VE Shimadzu device. COD, $\mathrm{BOD}_{5}$, chloride, nitrate, nitrite and sulphate concentrations were determined according to the standard methods selected by the American Public Health Association (1992).

\section{Results and Discussion}

The experimental results are gathered in Table 2 for various exposure times $t^{*}$ of the liming-unhairing worksop effluents to the discharge.

Table 2. Evolution with the exposure time $t^{*}$ to the gliding discharge of the liming -unhairing workshop effluent

\begin{tabular}{|c|c|c|c|c|c|c|c|c|c|}
\hline Time $t^{*}, \min$ & $\mathbf{p H}$ & Conduct. $\mu \mathrm{Scm}^{-1}$ & 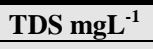 & TOC $\mathrm{mgL}^{-1}$ & $\mathrm{BOD}_{5} \mathrm{mgL}^{-1}$ & $\mathrm{Cl}^{-} \mathrm{mgL}^{-1}$ & $\mathrm{SO}_{4}{ }^{2-} \mathrm{mgL}^{-1}$ & $\mathrm{NO}_{2}^{-} \mathrm{mgL}^{-1}$ & $\mathrm{NO}_{3}^{-} \mathrm{mgL}^{-1}$ \\
\hline 0 & 13.2 & 19800 & 9950 & 21450 & 17360 & 1290 & 3000 & 435 & 702 \\
\hline 5 & 10.6 & 19910 & 9990 & 15100 & 8000 & 1350 & 3260 & 435 & 850 \\
\hline 10 & 10.2 & 19970 & 10000 & 15090 & 3120 & 1490 & 3696 & 420 & 1000 \\
\hline 20 & 9.5 & 20500 & 10700 & 15030 & 2720 & 1688 & 3987 & 325 & 1500 \\
\hline 30 & 8.4 & 20960 & 11050 & 14930 & 1845 & 1877 & 4130 & 330 & 1656 \\
\hline 40 & 7.2 & 21980 & 12070 & 12008 & 1562 & 1910 & 4350 & 517 & 2390 \\
\hline 60 & 5.4 & 23000 & 12700 & 987 & 1562 & 1960 & 5280 & 627 & 3975 \\
\hline 120 & 2.9 & & & & & 2060 & 5300 & 340 & 7014 \\
\hline
\end{tabular}

\subsection{Acidity, Conductivity and Nitrate Concentration Evolution}

As expected from other studies, the $\mathrm{pH}$ of a basic solution exposed to the gliding discharge in air usually decreases and the target solution trends to become acid. This feature is observed in the present study since the starting basic medium ( $\mathrm{pH}$ : 13.2 for $\mathrm{t}^{*}=0$ ) falls to $\mathrm{pH}: 5.4$ for $\mathrm{t}^{*}=60 \mathrm{~min}$, and even to very acid $\mathrm{pH}\left(\mathrm{pH}\right.$ : 2.9 for $\left.\mathrm{t}^{*}=120 \mathrm{~min}\right)$ for much longer exposure times. The pH vs.t* plot (not shown) has the general aspect of a typical neutralization plot of a concentrated strong base by a strong acid. Such behaviour is directly related with the increase in the Nitrate concentration, thus with the formation of nitric acid, and the matching conductivity.

This feature is explained by the formation of nitric oxide NO in the arc part of the discharge, in agreement with the Birkeland process. The endothermic formation of $\mathrm{NO}^{\circ}$ was identified by emission spectroscopy and probably obeys the Zeldovich model which involves the oxidation of $\mathrm{N}_{2}$ by $\mathrm{O}^{\circ}$ atoms which are provided by electron impact dissociation of $\mathrm{O}_{2}$ :

$$
\begin{gathered}
\mathrm{N}_{2}+\mathrm{O}^{\circ} \rightarrow \mathrm{NO}^{\circ}+\mathrm{N}^{\circ} \\
\mathrm{N}^{\circ}+\mathrm{O}_{2} \rightarrow \mathrm{NO}^{\circ}+\mathrm{O}^{\circ} \\
\mathrm{N}^{\circ}+\mathrm{O}^{\circ} \rightarrow \mathrm{NO}^{\circ}
\end{gathered}
$$

The limited stability of $\mathrm{NO}^{\circ}$ (lifetime of few seconds) is related with its reactivity. For example, $\mathrm{NO}^{\circ}$ reacts with $\mathrm{N}$ atoms at low temperature and also with oxygen or other oxygen donor moieties:

$$
\begin{gathered}
\mathrm{NO}^{\circ}+\mathrm{N}^{\circ} \rightarrow \mathrm{N}_{2}+\mathrm{O}_{2} \\
\mathrm{NO}^{\circ}+\mathrm{O}^{\circ} \rightarrow \mathrm{NO}_{2}+\mathrm{O}^{\circ}
\end{gathered}
$$


$\mathrm{NO}^{\circ}$ combines with ${ }^{\circ} \mathrm{OH}$ and forms nitrous acid:

$$
\mathrm{NO}^{\circ}+{ }^{\circ} \mathrm{OH}(+\mathrm{M}) \rightarrow \mathrm{HONO}(+\mathrm{M})
$$

and with $\mathrm{HO}_{2}{ }^{\circ}$ to yield peroxynitrous acid $\mathrm{ONOOH}$, the trans- form isomerizes into nitric acid. It may be additionally mentioned that nitrous acid is thermodynamically unstable in solutions at $\mathrm{pH}<6$ [9].

The acid effect observed in solutions with gliding discharges (and to a lesser extent with corona dischages) explains $\mathrm{pH}$ abatement, additionally to conductivity and nitrate concentration increases. The occurrence of a maximum for nitite is also verified in the present case for $\mathrm{t}^{*}>60 \mathrm{~min}$ and is attributed both to the lack of thermodynamic stability of nitrous acid HONO which disproportionates into $\mathrm{NO}_{3}{ }^{-}$and $\mathrm{NO}$ as mentioned.

The increase in chloride concentration may result of the breaking of the $\mathrm{C}-\mathrm{Cl}$ bonds by electron impact. The high oxidizing power of the peroxynitrite intermediate may then transform choride to volatile chlorine and other oxidized chlorine derivatives, as already considered.

The decrease in the conductivity of the solution during the first minutes of treatment is followed by an important increase after $60 \mathrm{~min}$ exposure. This behaviour may be ascribed to the development of the above mentioned reactions: the conductivity increase shows that new ionic species are generated in the medium and that the proton concentration becomes important.

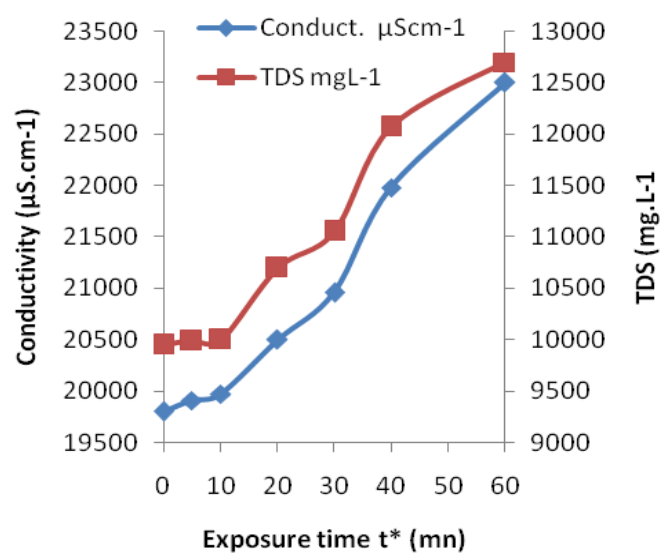

Fig. 2. Increase in conductivity and Total Dissolved Solids with the exposure time $t^{*}$

Figure 2 shows the continuously increasing evolution of total dissolved solids (TDS), in the same direction as conductivity. This feature may be related to the $\mathrm{pH}$ decrease and the matching increasing solubility of calcium carbonate since $\mathrm{Ca}(\mathrm{OH})_{2}$ is used for unhairing concurrently with more expensive $\mathrm{NaOH}$. Therefore, the growth curve from 60 minutes showed an increase of ionic salts in solution.

\subsection{TOC and $\mathrm{BOD}_{5}$}

The plasma treatment induces a considerable decline in TOC, starting from $21450 \mathrm{mg} \mathrm{L}^{-1}$ down to $987 \mathrm{mg} \mathrm{L}^{-1}$ for $\mathrm{t}^{*}$ $=60$ minutes exposure to the discharge, i.e., a reduction by
$95.4 \%$. For $20<\mathrm{t}^{*}, \min <35$, TOC very slowly decreases: a feature that may be attributed to the degradation of heavy organic compounds, involving for example the breaking of $\mathrm{C}-\mathrm{C}$ bonds and the formation of intermediates which slightly affects the TOC values. For exposure times longer than $t^{*}=$ $30 \mathrm{~min}$, TOC significantly decreases.

Taking experimental errors into account affords guessing a linear relationship between TOC and $t^{*}$ (Fig. 3)

$$
\text { TOC }\left(\mathrm{mgL}^{-1}\right)=-266.0 \mathrm{t} *(\min )+19820.4\left(\mathrm{R}^{2}=0.83\right)
$$

Such a behaviour would agree with an overall zero order kinetic $\mathrm{d}[\mathrm{TOC}] / \mathrm{dt}^{*}=-\mathrm{k}_{0}$ as already observed for the degradation of concentrate organic solutes.

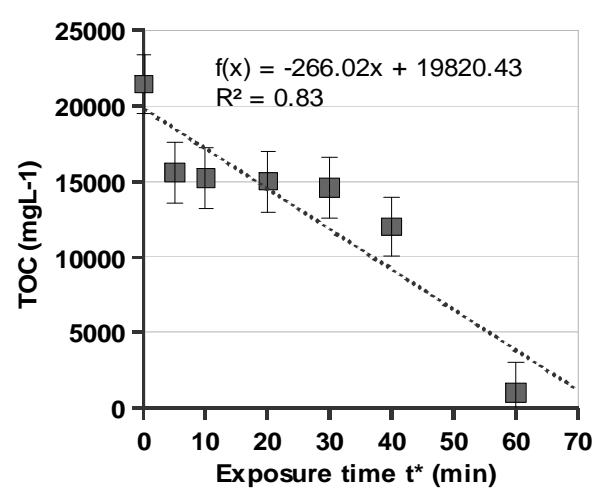

Fig. 3. Linear plot of tendency of the TOC values with increasing $t^{*}$ (min)

The $\mathrm{BOD}_{5}$ values also decrease with increasing $\mathrm{t}^{*}$, as does TOC. The evolution with $\mathrm{t}^{*}$ of the matching $\mathrm{BOD}_{5}$ abatement $\mathrm{G}$ (i.e., $\mathrm{G}=\left[\mathrm{BOD}_{5, \mathrm{t}^{*}=0}-\mathrm{BOD}_{5, \mathrm{t}^{*}}\right] / \mathrm{BOD}_{5, \mathrm{t}^{*}=0}$ ) is presented in Figure 4. The graph shows that the most important part of the $\mathrm{BOD}_{5}$ abatement is obtained for short exposure times $\mathrm{t}^{*}<10$ min since $\mathrm{G}$ is higher than $50 \%$ and even reaches $93 \%$ for $\mathrm{t}^{*}=40 \mathrm{~min}$.

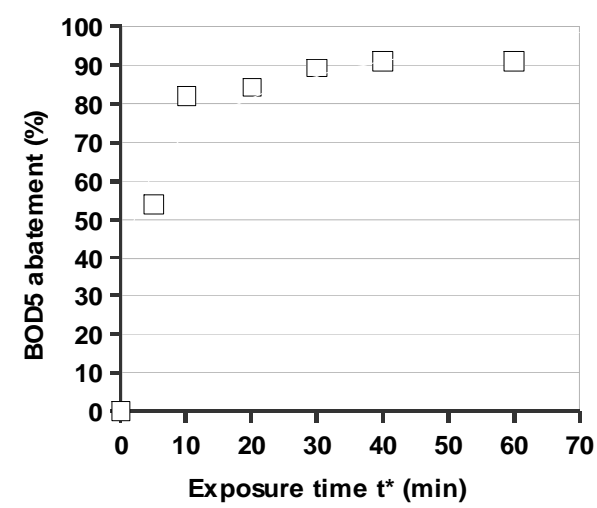

Fig. 4. Evolution of $B O D_{5}$ abatement $\triangle\left(B O D_{5}\right) /\left(B O D_{5 i}\right)=f\left(t^{*}\right)$ as a function of exposure time $t^{*}$

These experimental results are highly important because they confirm the pollutant abatement effect of the gliding discharge and its role in environmental processes. We showed that only $5 \mathrm{~min}$ treatments were sufficient to lower the TOC by $30 \%$ and $\mathrm{BOD}_{5}$ by $54 \%$. However, the exposure times required in this batch study are too long to get drinkable water by direct exposure to the discharge. Such a 
result with a laboratory scale device would require a too long exposure time which means a too high running cost of the process. In fact the efficacy of the glidarc treatment may be largely improved by increasing the contact between the discharge and the liquid target and using a loop to favour recycling. Also, the energy source used in the laboratory scale experiments may be developed, as was successfully performed in the frame of a European contract. Such developments may be undertaken for further pre-industrial studies.

\subsection{Bacterial Inactivation}

The known bactericidal effect of the gliding arc treatment is also verified in the case of the fecal coliforms detected in the untreated effluent samples. The number of CFU.100 $\mathrm{mL}^{-1}$ thus varied from 900 for $\mathrm{t}^{*}=0$ min down to 85 for $\mathrm{t}^{*}=5 \mathrm{~min}$ and was under the detection threshold for longer exposure times.

\section{Conclusion}

The experimental and preliminary results confirm that the used type of discharge induces a noticeable abatement of organic wastes and trends to make the effluents composition closer to the local standards. Acidity is largely lowered within $30 \mathrm{~min}$ treatment and $\mathrm{BOD}_{5}$ and TOC drastically decrease. On the opposite, the TDS, conductivity and nitrate and chloride concentrations values increase. The nitrite concentration presents a maximum as already observed [9]. We can guess that acidity increase favours the solubility of $\mathrm{CaCO}_{3}$ when used (which is often the case for economical reasons), and the resulting increase in TDS, conductivity, and Nitrogen salts concentrations: the formation of transient nitrite with the gliding arc process is known, as is that of the stable nitrate. It may be incidentally noted that a controlled increase in the stream might enhance growing cultures. The efficacy of the gliding arc treatment was also verified in the abatement of fecal coliforms for $t^{*} \geq 10 \mathrm{~min}$ in case of an actual sample.

In any case the encouraging results of the batch treatment may be improved by developing more powerful plasma source, other reactor devices and also by using circulating mode for the target solution.

\section{References}

[1] Njoyim-Tamungang E., Laminsi S., Ghogomu P., Njopwouo D., Brisset J.-L. (2011)- pollution control of surface waters by coupling gliding electric discharges treatments with incorporated oyster shell powder. Chem. Eng. J. 173 : 303-308
[2] Abdelmalek F., Ghezzar M., Belhadji M.,Addou A., Brisset J.L.(2006)- Bleaching and degradation of textile dyes by nonthermal plasma process at atmospheric pressure. Ind. Eng. Chem. Res. 45:23-29.

[3] Doubla A., Laminsi S., Nzali S., Njoyim E., Kamsu-Kom J., Brisset J.-L. (2007)- Organic pollutants abatement and biodecontamination of brewery effluents by non termal plasma at atmospheric pressure. Chemosphere 69:332-337.

[4] Moussa D., Brisset J.-L., Hnatiuc E., Decobert G. (2006)Plasma-chemical destruction of trilaurylamine from nuclear laboratories of reprocessing plants. Ind. Eng. Chem. Res. 45:30-33.

[5] Brisset J.-L., Moussa D., Doubla A., Hnatiuc E., Hnatiuc B., Kamgang Youbi G., Herry J.-M., Naitali M., Bellon-Fontaine M.-N. (2008)- Chemical reactivity of discharges and temporal post-discharges in plasma treatment of aqueous media. Examples of gliding discharges treated solutions. Ind. Eng. Chem. Res. 47: 5761-5781.

[6] Kamgang Youbi G., Herry J.-M., Brisset J.-L., BellonFontaine M.-N. , Doubla A., Naitali M. (2009)- Microbial investigation using a plasmachemical solution obtained by gliding electric discharges. Let. Appl. Microbiol.49: 13-18.

[7] Czernichowski A.(1994)- Gliding arc applications to engineering and environment control- Pure Appl. Chem. 66:1301-1310

[8] Benstaali B., Boubert P., Cheron B., Addou A., Brisset J.-L. (2002) Density and rotational temperatures measurements of the ${ }^{\circ} \mathrm{NO}$ and ${ }^{\circ} \mathrm{OH}$ radicals produced by a gliding arc in humid air and their interaction with aqueous solutions. Plasma Chem. Plasma Process. 22: 553-571.

[9] Brisset J.-L., Hnatiuc E. (2012) - Peroxynitrite: a reexamination of the chemical properties of non-thermal discharges burning in air over aqueous solutions- Plasma Chem. Plasma Process. 32: 655-674.

[10] Naitali M., Herry J.-M., Hnatiuc E., Kamgang Youbi G., Brisset J.-L.(2012)- Kinetics and bacterial inactivation induced by peroxynitrite by electric discharges in air. Plasma Chem. Plasma Process. 32: 675-692.

[11] Poznyak T., Araiza B(2005) -Ozonation of non bio-degradable mixtures of phenol and naphtalene derivatives in tanning waters- Ozone Sci. Eng. 27:351-357

[12] Rodriguez S., Sevens M., Germirii F., Aburja B. (2005)Combined chemical and biological oxidation of tannery wastewaters. $\mathrm{IO}_{3} \mathrm{~A}$ Congress, Strasbourg, France.

[13] Hammami S., Ouejhani A., Bellakhal N., Dachraoui M. (2009)- Application of Doehlert matrix to determienthe optimal conditions of electrochemical treatment of tannery effluents.- J. Hazard Mater. 163:251-258. 